\title{
Experimental Investigation on the Performance and Emission Characteristics of Hydrogen Fueled SI Engine
}

\author{
P. Tamilarasan* and M. Loganathan \\ Department of Mechanical Engineering, Annamalai University, Annamalainagar, Chidambaram - 608002, \\ Tamil Nadu, India; ptIme@live.com, logu692002@rediffmail.com
}

\begin{abstract}
Background/Objectives: With the huge increase of fuel price, shortage of cured oil supply and air pollutions due to engine exhaust emission has made the authors to focus on the utilization of alternative fuels in SI engine, improving engine fuel economy and reducing the exhaust emission. The main objectives of this work is to utilize the alternative fuel, increase the performance, and to reduce the engine exhaust emissions like $\mathrm{HC}, \mathrm{CO}, \mathrm{CO}_{2}$ and NOx produced by the hydrogen fueled SI engine. Methods/Statistical Analysis: The SI engine was designed and modified to supply hydrogen manifold injection by using gaseous hydrogen injector installed in the intake manifold. The ignition timing maintained at optimum spark timing for best torque of the engine. The equivalence ratio was varied from 0.82 to 1.27 and 0.57 to 1.03 for gasoline and hydrogen operations respectively. The comparison of the fuel consumption, brake thermal efficiency and engine emissions running on gasoline and hydrogen fuel was done separately at a constant speed of $3000 \mathrm{rpm}$ and at variable load conditions. Findings: For hydrogen operation, a lean equivalence ratio of around 0.6 was attained, whereas it was 0.82 with gasoline operation. The Brake-Specific Fuel Consumption (BSFC) lowers than gasoline as compared with hydrogen fuel at the higher thermal efficiency point. $\mathrm{HC}, \mathrm{CO}$, and $\mathrm{CO}_{2}$ emissions were negligible with hydrogen fuel. $\mathrm{NO} x$ is the only major regulatory emission present in the pure hydrogen fuel operation. NOx emission is very low at lower equivalence ratios. However, it was significantly higher than gasoline fuel at an equivalence ratio of 0.99 due to increased cylinder temperature. $\mathrm{HC}, \mathrm{CO}$, and $\mathrm{CO}_{2}$ emissions are negligible. Application/Improvements: This paper presents the experimental study conducted on a single cylinder, low power, SI engine fueled with hydrogen to evaluate its performance and emissions characteristics. The test results showed that the improved brake thermal efficiency was achieved at a lean equivalence ratio with hydrogen fuel. For hydrogen fuel operation, there is an increase of 3.59\% brake thermal efficiency than the gasoline fuel at $1.44 \mathrm{~kW}$ power. However, there is an $18 \%$ reduction in the peak output power of the engine when operated with the hydrogen fuel. HC, CO, and $\mathrm{CO}_{2}$ emissions were very low for hydrogen operations when compared with gasoline.
\end{abstract}

Keywords: Emission Characteristics, Hydrogen Injector, Hydrogen Fuel, Manifold Injection, SI Engine, Thermal Efficiency

\section{Introduction}

The decreasing rate of fossil fuel reserves and stringent regulations on emission norms have forced many researchers to focus on alternative fuels. Hydrogen has long been accepted one of the green alternative fuel for internal combustion engine by many researchers $\frac{1-4}{}$. It has many good characteristics that make it an attractive alternative fuel $\frac{5,6}{.6}$. Hydrogen fuel never produces greenhouse gases or air pollutants when used in fuel cells technologies and it produces only $\mathrm{NO}_{x}$ emission when used in internal combustionengines $\frac{7-10}{}$. As a result, it has been used as an alternative to conventional fuels for internal combustion engine ${ }^{11}$.

*Author for correspondence 
Owing to the very high hydrogen auto-ignition temperature around $858 \mathrm{~K}^{\frac{12}{2}}$, it is very appropriate to equip hydrogen on Spark Ignition (SI) engine when compared with Compression Ignition (CI) engine. The hydrogen engine produces higher efficiency than the gasoline engine due to its positive properties $\frac{13}{}$. Hydrogen has several unique combustion characteristics that improves efficiency and emissions of the engine. The hydrogen fuel possess high adiabatic flame velocity makes that the combustion very close to a constant volume combustion process, which helps to increase brake thermal efficiency ${ }^{14,15}$. The energy value by volume basis of hydrogen fuel is much lower than gasoline, therefore hydrogen operated engines works better by using its good properties and sometime also suffer with weak torque output $\frac{16}{}$.

The ignition energy required for the combustion of hydrogen fuel is nearly 10 times lower than gasoline fuel, so it can be very easily ignited when compared with pure gasoline fuel. So, the hydrogen engine starts smoothly and good stability in operating under lean conditions $\frac{17,18}{,}$. Hydrogen shows the main distinctive features of a practically acceptance carbon-free fuel. The present work focuses on evaluating the performance and emission fueled with hydrogen and the results were compared with that of gasoline.

Table 1. Specification of test engine

\begin{tabular}{|l|l|}
\hline Item & Value \\
\hline Engine & Greaves Cotton \\
\hline Type & $4-$ Stroke \\
\hline Power & $2.2 \mathrm{~kW}$ \\
\hline Speed & $3000 \mathrm{rpm}$ \\
\hline Bore & $70 \mathrm{~mm}$ \\
\hline Stroke & $67.7 \mathrm{~mm}$ \\
\hline Displacement & $256 \mathrm{CC}$ \\
\hline Compression Ratio & $4.67 / 10.33: 1$ \\
\hline No. of Cylinder & One \\
\hline
\end{tabular}

Limited studies have been reported on the engine performance and emission of hydrogen-fueled SI engine at various equivalence ratio conditions. So, there was a strong reason for studying the performance and emission of a hydrogen fueled SI engine at different load conditions. In this work, a conventional gasoline operated engine was used and it was modified into a hydrogen manifold injection engine by mounting a fuel injection system in the inlet manifold using a special hydrogen gas injector (quantum injector). An Electronic Control Unit (ECU) was installed and it is used to control the closing and opening of hydrogen injector, injection timing, spark timing, and duration of injection.

Table 2. Properties of gasoline and hydrogen fuels

\begin{tabular}{|l|l|l|l|}
\hline Property & Units & Gasoline & Hydrogen \\
\hline $\begin{array}{l}\text { Density at } 1 \mathrm{~atm} \text { and } \\
300 \mathrm{~K}\end{array}$ & $\mathrm{Kg} / \mathrm{m}^{3}$ & 730 & 0.083 \\
\hline $\begin{array}{l}\text { Stoichiometric fuel } \\
\text { air mass ratio }\end{array}$ & - & 0.0664 & 0.029 \\
\hline Lower heating value & $\mathrm{MJ} / \mathrm{kg}$ & 44.79 & 119.7 \\
\hline $\begin{array}{l}\text { Kinematic viscosity } \\
\text { at 300K }\end{array}$ & $\mathrm{mm}^{2} / \mathrm{s}$ & 1.18 & 110 \\
\hline $\begin{array}{l}\text { Thermal conductivity } \\
\text { at 300K }\end{array}$ & $\mathrm{mW} / \mathrm{m} \mathrm{K}$ & 11.2 & 182 \\
\hline $\begin{array}{l}\text { Diffusion coefficient } \\
\text { into air at NTP }\end{array}$ & $\mathrm{cm} / \mathrm{s}$ & 0.05 & 0.61 \\
\hline Flammability limits & $\%$ by vol. & $1.2-6.6$ & $4-75$ \\
\hline $\begin{array}{l}\text { Minimum ignition } \\
\text { energy }\end{array}$ & $\mathrm{mJ}$ & 0.25 & 0.02 \\
\hline $\begin{array}{l}\text { Laminar flame speed } \\
\text { at NTP }\end{array}$ & $\mathrm{m} / \mathrm{s}$ & $0.37-0.43$ & 1.90 \\
\hline $\begin{array}{l}\text { Adiabatic flame } \\
\text { temperature }\end{array}$ & $\mathrm{K}$ & $\sim 2470$ & 2318 \\
\hline $\begin{array}{l}\text { Auto ignition } \\
\text { temperature }\end{array}$ & $\mathrm{K}$ & $\sim 550-750$ & 858 \\
\hline $\begin{array}{l}\text { Quenching gap at } \\
\text { NTP }\end{array}$ & $\mathrm{mm}$ & 2.0 & 0.64 \\
\hline
\end{tabular}

The experiments were carried out on a SI engine with hydrogen manifold injection system using a hydrogen injector at full throttle (WOT) and at a constant speed of $3000 \mathrm{rpm}$. The test results obtained during the experiment of plain gasoline operation was compared with hydrogen. The variations of brake power output, brake specific fuel consumption (BSFC), engine exhaust gas temperature, thermal efficiency and emissions such as $\mathrm{HC}, \mathrm{CO}_{2}, \mathrm{CO}$ and $\mathrm{NO}_{x}$ against equivalence ratios are evaluated and compared gasoline fuel operation with hydrogen. Moreover, slight engine design modifications have been made to increase the compression ratio from 4.67(original) to 10.33 .

\section{Experimental Set up}

Figure1 shows the schematic representation of the experimental setup used in this work. A single cylinder 256 CC 
air-cooled 4-stroke spark ignition engine was used in this experimental work. The specifications of the test engine are listed in Table 1. An eddy current dynamometer was coupled with the engine to control the load and speed by adjusting a set of control knobs present in the dynamometer control panel. An electronic control system was used to control the air-fuel ratio, injection timing, and spark timing of the engine. Signal from the crank position sensor (Kistler's) installed on the main shaft is sent to the electronic fuel injector. The gasoline and hydrogen properties are listed in Table 2. Gaseous hydrogen stored in a container with a gas purity of $99.995 \%$ and it was fed into the engine through safety devices. Hydrogen was stored in the cylinder at a pressure of 140bar which can be reduced into 2 bar using a double stage pressure regulator. Hydrogen flow rate was measured by using a digital mass flow meter with an accuracy of $0.2 \%$ at full scale. Gasoline flow rate was measured by using a digital weighing machine with 0.5 grams accuracy. To prevent backfiring of hydrogen from the engine intake manifold, gas from the cylinder is allowed to pass through a series of safety devices such as water base flame trap, chemical based flame arrestor and non-return type flashback arrestor to ensure safety. Hence the travel of flame from the engine to cylinder was stopped by these devices and to prevent the dangerous hazards around the experimental setup. A photographic view of hydrogen supply line with necessary safety devices is shown in Figure 2. The hydrogen gas was transported form high pressure gas cylinder to the engine intake manifold through a number of safety devices by means of $10 \mathrm{~mm}$ steel tubes with some bents and joints. Hydrogen gas is a colorless, odorless and highly flammable gas and it is impossible to identify the leak in flow line and joints by human senses. Hence a portable hydrogen leak detector was also used during the

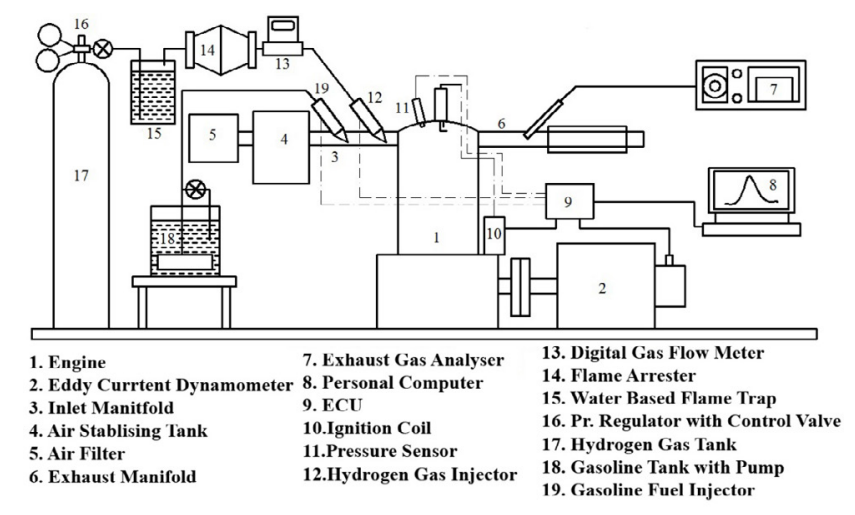

Figure 1. Schematic view of experimental setup. experimentation process to find the leakages of gas in the flow line. The small quantity of dry exhaust gas was taken from the exhaust manifold and fed it to the gas analyser. The constituents of exhaust gas such as $\mathrm{HC}, \mathrm{CO}, \mathrm{CO}_{2}, \mathrm{O}_{2}$ and $\mathrm{NO} x$ were measured in this work by using an Horiba MEXA-534L exhaust gas analyser. The analyser was calibrated frequently before starting the experiments for its accuracy by means of calibration gases of known concentrations. At end of each test calibration was rechecked to confirm not to undergo deviations during experimental test.

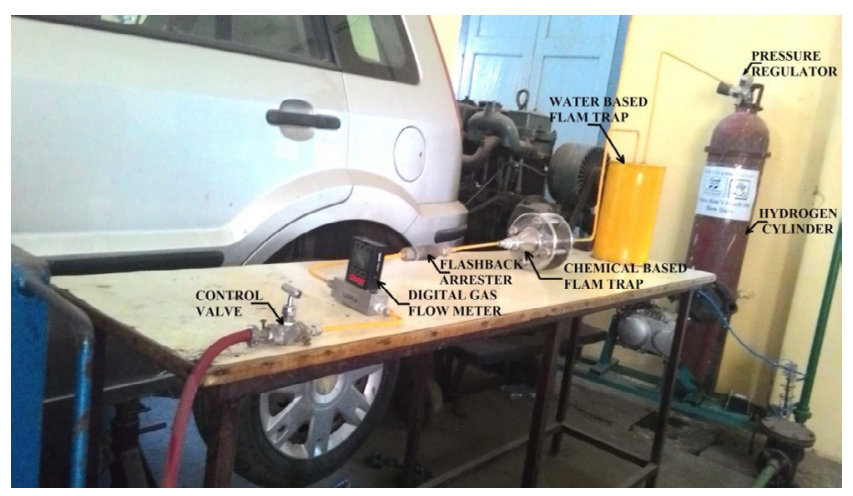

Figure 2. Photographic view of hydrogen supply line.

\section{Experimental Procedure}

The investigation was conducted on an engine at constant speed of $3000 \mathrm{rpm}$. The gasoline and hydrogen gas flow rate can be adjusted by adjusting the injection duration to gain different equivalence ratios. The tests were conducted with gasoline as fuel by using an electronic gasoline injector and then the engine was run with hydrogen by using the gaseous fuel injector. The quantity and the timing of injection of hydrogen are varied by an electronic control unit. In SI engine spark timing gives a big impact on the engine performance and emission characteristics. So in this work, optimum spark timing (MBT) was maintained throughout the experiments. Digital Alicat gas flow meter was used to measure the flow rate of hydrogen gas at full scale accuracy of $0.2 \%$. The mass flow rate of gasoline was directly measure by means of digital weighing machine with accuracy of 0.5 grams. The engine performance and emissions for gasoline and hydrogen operation were compared and analyzed. Dry engine exhaust gas was analyzed for various compositions such as $\mathrm{NO}_{x}, \mathrm{CO}, \mathrm{HC}, \mathrm{CO}_{2}$, and $\mathrm{O}_{2}$. And magnitude of emissions by an exhaust gas analyser. Horiba MEXA analyser was used in this work to determine the amount of emission present in the exhaust 
gas. The air-fuel ratio was also captured by a Horiba MEXA analyser by using an $\mathrm{O}_{2}$ sensor firmly inserted in the exhaust line. During the experiments, temperature of lubricant oil maintained at $91^{\circ} \mathrm{C}$ to $95^{\circ} \mathrm{C}$, to eliminate its bad effects on the experimental results.

\section{Results and Discussion}

The detailed analysis of performance and engine exhaust gas emissions of a gasoline and hydrogen fueled SI engine were presented and discussed in the below divisions.

\subsection{Brake Power}

Figure 3 shows the relationship between brake power and the equivalence ratio for gasoline and hydrogen operations. From the following graph, it was found that the peak brake power output attained is about $2.2 \mathrm{~kW}$ for gasoline operation, whereas for hydrogen, it was about $1.804 \mathrm{~kW}$. Hydrogen fueled engine produces only $82 \%$ of brake power output of original gasoline fueled engine. Owing to the backfiring and knock in the inlet manifold, higher power outputs were not attainable by the engine. This is because of few amount of hydrogen gas collected in the intake manifold. Backfire occurs because of the accumulation of gas present in the intake manifold due to higher injection duration than the inlet valve open period and it was ignited by the exhaust gas and hot spot nearer to the inlet valve. Hydrogen has a low gas density which displaces an equal quantity of fresh air by its own volume producing the reduction of mixture amount as a result; there is a significant drop in power output. In addition to it, strength of mixture is more than an equivalence ratio of 1.05 which leads to knock and rapid combustion.

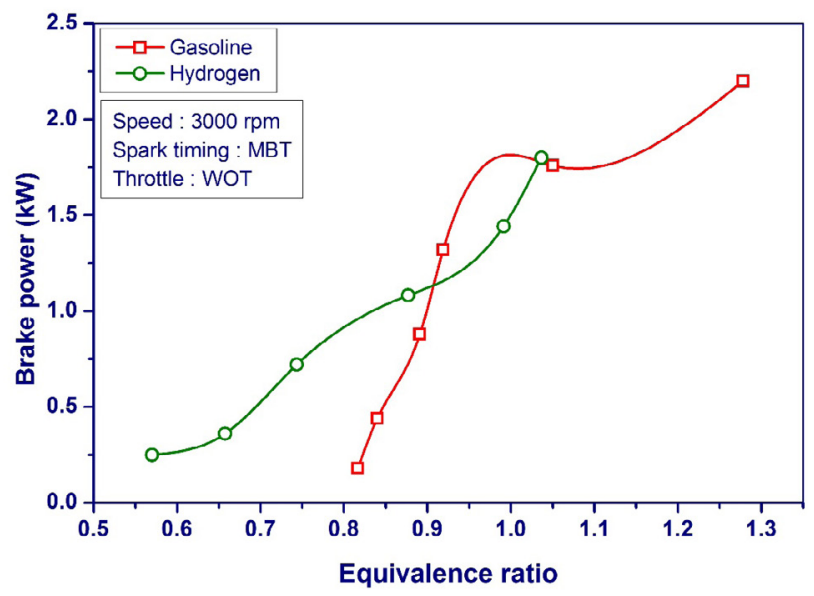

Figure 3. Variations of brake power with equivalence ratio.

\subsection{Brake Specific Fuel Consumption}

Figure 4 shows the relationship between BSFC and brake power. As expected, the BSFC of hydrogen fuel was considerable lower than gasoline. For gasoline operation, BSFC is around $0.247 \mathrm{~kg} / \mathrm{kWh}$ and it was about 0.096 $\mathrm{kg} / \mathrm{kWh}$ for hydrogen at the very best brake thermal efficiency point. The main causes of increased brake thermal efficiency of hydrogen engine were the higher energy content of hydrogen compared to gasoline.

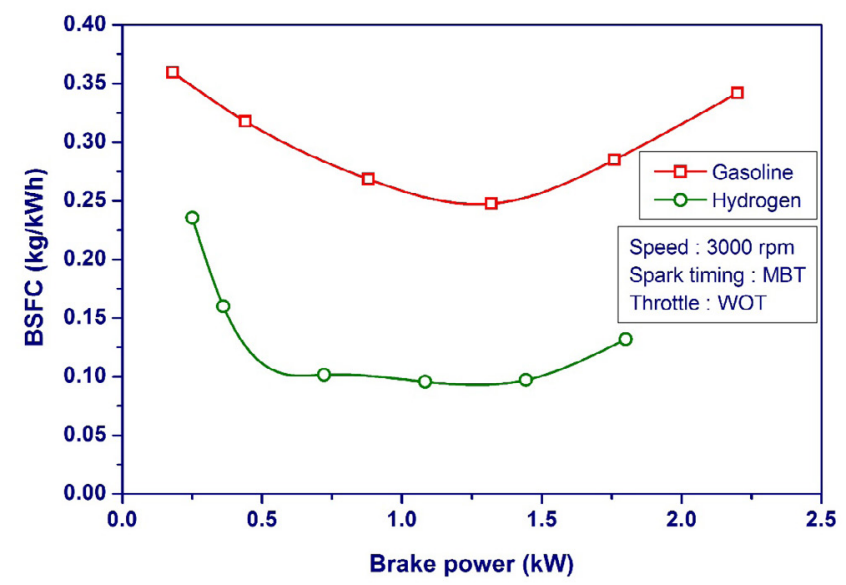

Figure 4. Variations of BSFC with brake power.

\subsection{Brake Thermal Efficiency}

Figure 5 shows the comparison of brake thermal efficiency with equivalence ratio for both hydrogen and gasoline operations. The peak thermal efficiency is about 30.3\% could be obtained for gasoline operation at a maximum equivalence ratio of 1.05 and for hydrogen it is around $31.39 \%$ at the equivalence ratio of 0.99 . Thus, the thermal

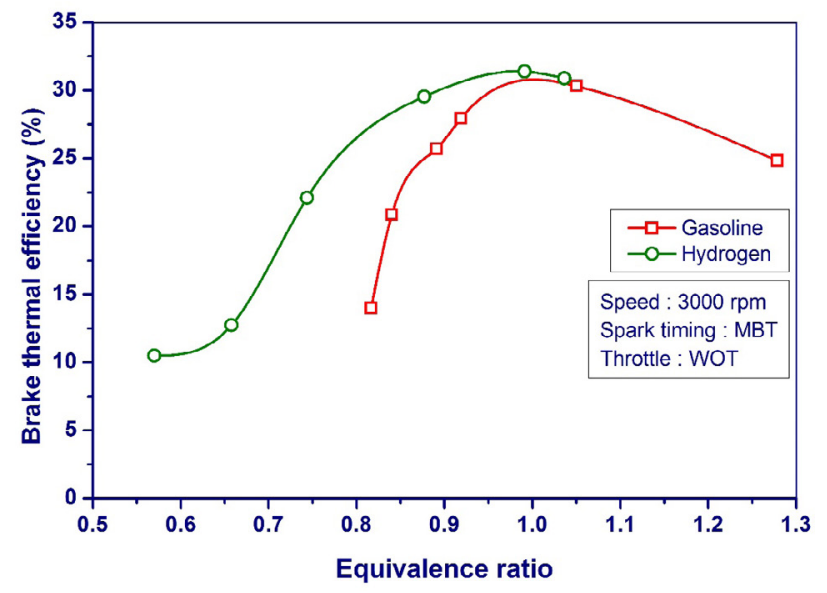

Figure 5. Variations of brake thermal efficiency with equivalence ratio. 
efficiency was increased of about $1.09 \%$. In other words, thermal efficiency of hydrogen operation is $3.59 \%$ higher, when compared with gasoline operations. This is due to the quick burning of hydrogen because combustion occur almost at near constant volume and also hydrogen enhances the thermal efficiency when engine runs at lean mixtures.

\subsection{HC Emission}

Figure 6 shows the effect of hydrocarbon emission with equivalence ratio for hydrogen and gasoline. The $\mathrm{HC} \mathrm{lev-}$ els were available in the exhaust gas in between the range of 456 to $732 \mathrm{ppm}$ by the gasoline operation. The HC emission levels available in the engine exhaust was lower than that of gasoline when compared with hydrogen operation. A negligible amount of $\mathrm{HC}$ emission available in the engine exhaust during hydrogen operations, this is because of non-existence of carbon atom in the hydrogen. HC emission was present in the engine exhaust gas with hydrogen operation is negligible; this is due to the absence of carbon atom in the hydrogen gas. Even though there is no carbon present in the hydrogen, negligible amounts of $\mathrm{HC}, \mathrm{CO}$ and $\mathrm{CO}_{2}$ present in the exhaust gas, these were caused by the combustion of lubrication oil in the combustion chamber.

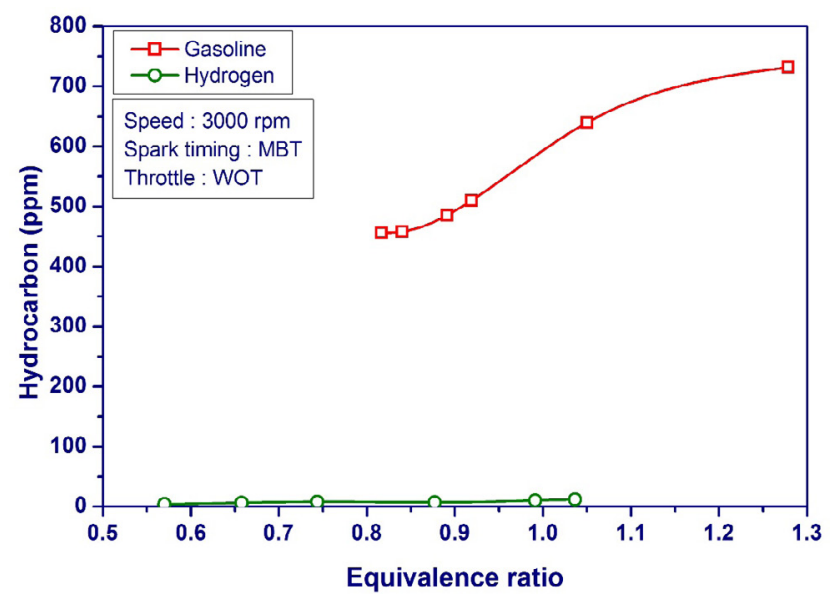

Figure 6. Variations of hydrocarbon emission with equivalence ratio.

\section{5 $\mathrm{NO}_{\mathrm{x}}$ Emission}

At lean condition the $\mathrm{NO}_{x}$ level is much lower than at the rich condition. The major advantage of the hydrogen engine is very lower NOx emission can be attained, when the engine runs at lean mixture condition. Hydrogen can produce significantly very high $\mathrm{NO}_{x}$ than gasoline operation at equivalence ratios nearer to the best thermal efficiency. From Figure 7, it is noticed that, up to equivalence ratio abut 0.74 , the $\mathrm{NO}_{x}$ emissions were almost low. This is because of large amount of air enters the combustion, which reduces the bulk temperature and sequentially reduction in overall combustion temperature. The brunt gas temperature gradually raises up beyond the equivalence ratio of 0.74 and it increases rate of combustion, subsequently produces raises in $\mathrm{NO} x$ emission. Therefore, the $\mathrm{NO}_{x}$ emission tends to increases at an equivalence ratio above $0.74 . \mathrm{NO}_{x}$ formation is also attributed by the availability of excess oxygen. The $\mathrm{NO}_{x}$ concentration reached to a peak value of about $5890 \mathrm{ppm}$ at the equivalence ratio of around 0.99 . It was found that increase of brake power in terms of equivalence ratio which decreases the $\mathrm{NO}_{x}$ emission. This is because of the less oxygen supply due to decreased air consumption.

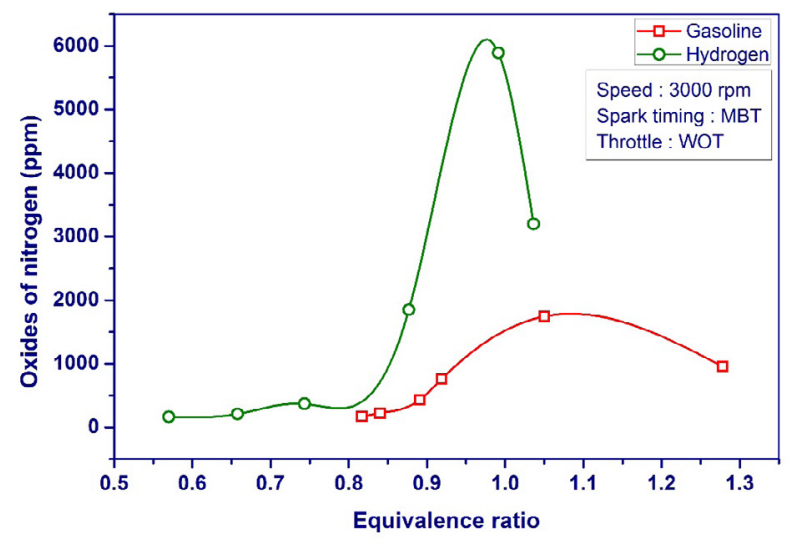

Figure 7. Variations of oxides of nitrogen with equivalence ratio.

\subsection{Exhaust Gas Temperature}

Figure 8 shows the relationship between the exhaust gas temperature and equivalence ratio. Exhaust gas temperature was increased gradually with equivalence ratio for both hydrogen and gasoline operations. For hydrogen operations, exhaust gas temperature was lower than the gasoline operation during lean conditions. Exhaust gas temperature was increased after an equivalence ration of 0.75 . The maximum temperature of exhaust gas of hydrogen operation at peak load is $428^{\circ} \mathrm{C}$ at 1.05 equivalence ratio, whereas for gasoline is $327 \mathrm{C}$ at an equivalence ratio of 1.3 . 


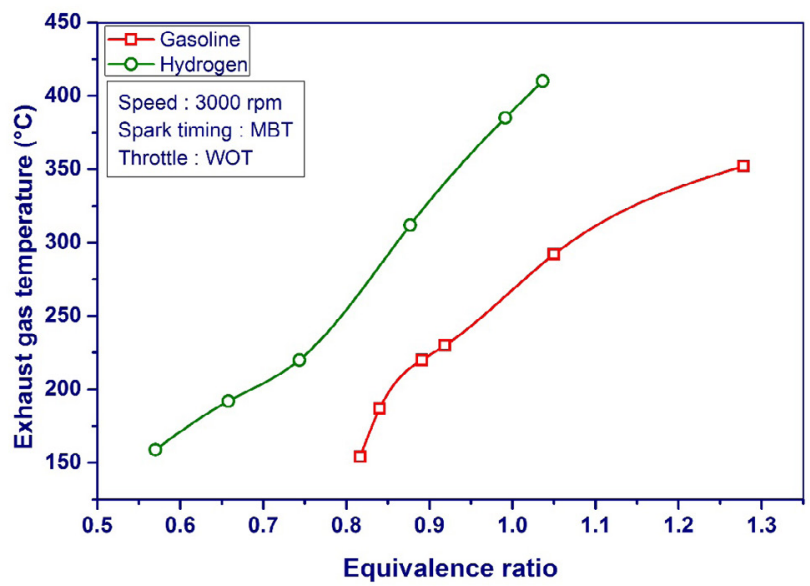

Figure 8. Variations of exhaust gas temperature with equivalence ratio.

\section{7 $\mathrm{CO}$ and $\mathrm{CO}_{2}$ Emissions}

Figures 9 and 10 show the comparison of $\mathrm{CO}$ and $\mathrm{CO}_{2}$ emissions with equivalence ratio. During hydrogen operation, there is a negligible amount of either $\mathrm{CO}$ or $\mathrm{CO}_{2}$ were exist in the engine exhaust gases. It was happened due to the lack of carbon atoms present in the hydrogen fuel. However, a very little amount of $\mathrm{CO}$ and $\mathrm{CO}_{2}$ available in the engine exhaust because of the present of lubricant oil along with the hydrogen gas in the engine cylinder during combustion.

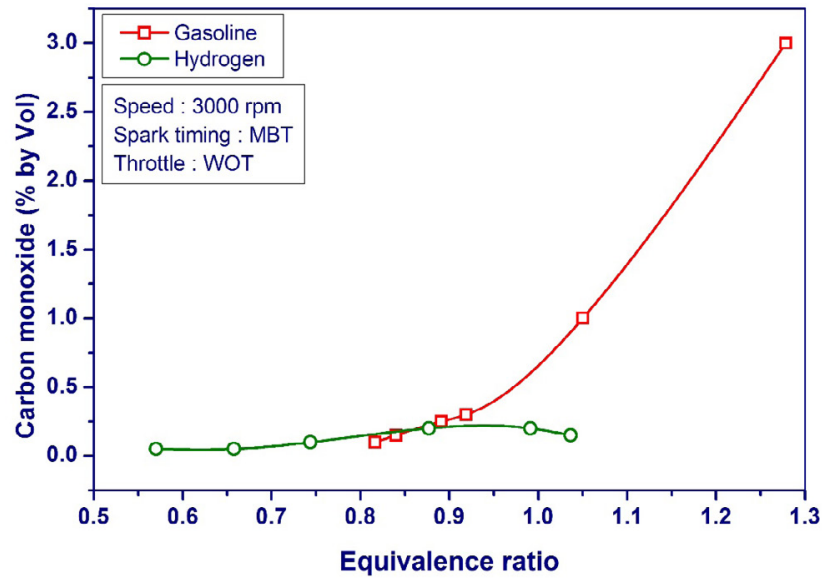

Figure 9. Variations of carbon monoxide with equivalence ratio.

\section{Conclusion}

In this present work, a conventional SI engine was converted into a hydrogen fueled engine with manifold injection technique. Experiments were conducted with

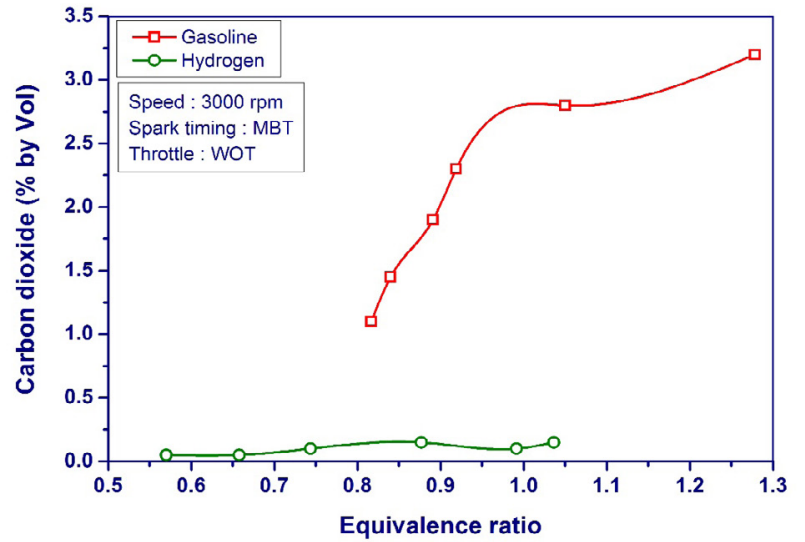

Figure 10. Variations of carbon dioxide emission with equivalence ratio.

gasoline and hydrogen as fuel. From the experimental investigations, the following conclusions were made.

The engine was run smoothly between the equivalence ratio 0.6 to 1.03 with hydrogen fuel, more than that the engine knocks and backfires, whereas the equivalence ratio was in the range of $0.78-1.28$ for gasoline operations.

It was found that the peak brake power with hydrogen engine is around $82 \%$ of original gasoline fueled engine operation. For gasoline operations thepeak brake thermal efficiency is $30.3 \%$ at an equivalence ratio of 0.99 , whereas it was about $31.39 \%$ at an equivalence ratio of 1.05. Therefore, there is an increase of $3.59 \%$ in thermal efficiency by hydrogen when compared with gasoline fueled engine.

$\mathrm{HC}$ emission available in the engine exhaust gas was very low with hydrogen operation, and $\mathrm{NO}_{x}$ levels were significantly more than gasoline fuel above 0.74 equivalence ratio. The maximum $\mathrm{NO}_{x}$ about 5890 ppm obtained for hydrogen operation at 0.99 corresponding to a brake power of $1.44 \mathrm{~kW}$, whereas for gasoline fuel operation, it was around $1746 \mathrm{ppm}$ at the equivalence ratio of 1.05 . However, up to 0.74 equivalence ratio $\mathrm{NO}_{x}$ emission was negligible with hydrogen when compared with gasoline.

\section{References}

1. Sastri MVC. Hydrogen energy research and development in India an overview. International Journal of Hydrogen Energy. 1987; 12(3):137-45. https://doi.org/10.1016/03603199(87)90145-5

2. Veziroglu TN, Barbir FH. Hydrogen, the wonder fuel. International Journal of Hydrogen Energy. 1992; 17(6):391404. https://doi.org/10.1016/0360-3199(92)90183-W 
3. Ferguson CR, Kirkpatrick AT. Internal combustion engines. New York: John Wiley and Sons; 2001.

4. Tamilarasan P, Loganathan M. Effect of water Injection on NOx emission and combustion of a hydrogen-fueled SI engine. Middle-East Journal of Scientific Research. 2016; 24(9):2957-66

5. Huang Z, Wang J, Liu B, Zeng K, Yu J, Jiang D. Combustion characteristics of a direct-injection engine fueled with natural gas-hydrogen blends under different ignition timings. Fuel. 2007; 86(3):381-7. https://doi.org/10.1016/j. fuel.2006.07.007

6. Saravanan N, Nagarajan G, Sanjay G, Dhanasekaran C, Kalaiselvan KM. Combustion analysis on a DI diesel engine with hydrogen in dual fuel mode. Fuel. 2008; 87(17):35919. https://doi.org/10.1016/j.fuel.2008.07.011

7. Verhelst S, Sierens R, Verstraeten S. Development of a simulation code for hydrogen fuelled SI engines. ASME 2006 Internal Combustion Engine Division Spring Technical Conference. American Society of Mechanical Engineers; 2006. https://doi.org/10.1115/ices2006-1317

8. Susan MS. Hydrogen vehicle fueling alternatives: An analysis developed for the international energy agency. SAE World Congress; No. 2001- 01-2528.

9. Verhelst S, Sierens R. Hydrogen engine-specific properties. International Journal of Hydrogen Energy. 2001; 26(9):98790. https://doi.org/10.1016/S0360-3199(01)00026-X

10. Karim GA. Hydrogen as a spark ignition engine fuel. International Journal of Hydrogen Energy. 2003; 28(5):569_ 77 https://doi.org/10.1016/S0360-3199(02)00150-7

11. Sainz D, Dieguez PM, Urroz JC, Sopena C, Guelbenzu E, Perez-Ezcurdia A, Benito-Amurrio M, S. Marcelino-Sadaba S, Arzamendi G, Gandi LM. Conversion of a gasoline engine-generator set to a bi-fuel (hydrogen/gasoline) electronic fuel-injected power unit. International Journal of Hydrogen Energy. 2011; 36(21):13781-92. https://doi. org/10.1016/j.ijhydene.2011.07.114

12. Das LM. Hydrogen-oxygen reaction mechanism and its implication to hydrogen engine combustion. International Journal of Hydrogen Energy. 1996; 21(8):703-15. https:// doi.org/10.1016/0360-3199(95)00138-7

13. Verhelst S, Maesschalck $P$, Rombaut N, Sierens R. Efficiency comparison between hydrogen and gasoline, on a bi-fuel hydrogen/gasoline engine. International Journal of Hydrogen Energy. 2009; 34(5):2504-10. https://doi. org/10.1016/j.ijhydene.2009.01.009

14. Andrea TD, Henshaw PF, Ting DSK. The addition of hydrogen to a gasoline fuelled SI engine. International Journal of Hydrogen Energy. 2004; 29(14):1541-52. https://doi. org/10.1016/j.ijhydene.2004.02.002

15. Heywood JB. Internal combustion engine fundamentals. McGraw-Hill Book Co; 2004 PMCid:PMC1732617

16. Ganesh RH, Subramaniyan V, Balasubramanian V, Mallikarjuna JM, Ramesh A, Sharma RP. Hydrogen fueled spark ignition engine with electronically controlled manifold injection: An experimental study. Renewable Energy. 2008; 33(6):1324-33. https://doi.org/10.1016/j. renene.2007.07.003

17. White CM, Steeper RR, Lutz AE. The hydrogen-fueled internal combustion engine: A technical review. International Journal of Hydrogen Energy. 2006; 31(12):1292-130. https://doi.org/10.1016/j.ijhydene.2005.12.001

18. Kahraman E, Ozcanl SC, Ozerdem B. An experimental study on performance and emission characteristics of a hydrogen fuelled spark ignition engine. International Journal of Hydrogen Energy. 2007; 32(12):2066-72. https:// doi.org/10.1016/j.ijhydene.2006.08.023 